\title{
Sistem Pakar Mendiagnosa Penyakit Tanaman Kakao Menggunakan Metode Certainty Factor
}

\author{
Linda Meniati*, Nur Yanti Lumban Gaol **, Ismawardi Santoso** \\ * Sistem Informasi, STMIK Triguna Dharma, Medan \\ ** Sistem Informasi, STMIK Triguna Dharma Medan
}

\section{Article Info}

Article history:

Received Jan $02^{\text {th }}, 2022$

Revised Jan $15^{\text {th }}, 2022$

Accepted Jan $27^{\text {th }}, 2022$

\section{Keyword:}

Certainty Factor

Kakao

Hama

Sistem Pakar

Theobroma Cacao

\begin{abstract}
Kakao (theobroma cacao) salah satu tanaman yang menghasilkan nilai ekonomis yang tinggi. Berbagai produk dapat dihasilkan dari pengolahan mulai dari biji hingga lemak, contohnya coklat yang bahan utama pembuatannya dari kakao, tidak hanya memiliki nilai jual tinggi kakao juga memiliki manfaat yang baik dalam bidang kesehatan karena buah kakao mengandung antioksidan berkhasiat meningkatkan kekebalan tubuh. Namun seringkali menghadapi kendala yaitu serangan hama atau penyakit yang terdapat pada tanaman kakao, seperti yang terjadi di Desa Pardomuan 2 yang mana tanaman kakao merupakan sumber pendapatan yang tinggi di daerah tersebut. Solusinya mengadopsi sistem pakar dengan menerapkan metode Certainty Factor (CF). Penelitian ini bertujuan untuk mendiagnosa penyakit pada tanaman kakao. Hasil perhitungan berdasarkan gejala yang dikeluhkan petani memiliki presentase tingkat keyakinan paling tinggi adalah $90.56 \%$ mengarah pada Penyakit Penggerek buah, sehingga dapat disimpulkan tanaman kakao tersebut di diagnosa terkena Penyakit Penggerek buah.
\end{abstract}

\section{Corresponding Author:*}

Nama : Linda Meniati

Program Studi : sistem informasi

Afiliasi : STMIK Triguna Dharma

Email: lindameniati10@gmail.com

\section{PENDAHULUAN}

Kakao (Theobroma Cacao) salah satu tanaman yang menghasilkan nilai ekonomis yang tinggi. selain itu, devisa di Indonesia juga mengalami kenaikan berkat produksi kakao. Berbagai produk dapat dihasilkan dari pengolahan mulai dari biji hingga lemak, contohnya coklat yang bahan utama pembuatannya dari kakao, tidak hanya memiliki nilai jual tinggi kakao juga memiliki manfaat yang baik dalam bidang kesehatan karna buah kakao memiliki atau mengandung antioksidan yaitu fenol dan flavonoid yang berkhasiat meningkatkan kekebalan tubuh [1].

Sebagai salah satu penghasil kakao, Indonesia harus dapat meningkatkan mutu biji kakao menjadi sebuah produk agar dapat bersaing dengan negara-negara penghasil kakao lainnya sehingga mendapatkan keuntungan yang optimal. Peningkatan produksi hasil pertanian dapat dilakukan dengan memanfaatkan kemajuan teknologi [2].

Namun kenyataanya dalam bercocok tanam kakao seringkali menghadapi sebuah kendala yaitu serangan hama atau penyakit yang terdapat pada tanaman kakao, seperti di Desa Pardomuan 2 yang mana tanaman kakao merupakan sumber pendapatan yang tinggi di daerah tersebut.

Serangan hama yang relatif tinggi dipengaruhi oleh beberapa faktor [3], yakni penyuluhan yang minim dan bimbingan teknis yang diberikan kepada petani sehingga mengakibatkan para petani memiliki keterbatasan pengetahuan untuk mengelola kebun kakao, dimana hal ini yang mengakibatkan terjadinya penurunan produksi. Ada tiga hal yang menjadi kendala utama di Desa Pordomuan 2, antara lain kurangnya ketersediaan lahan baik dalam hal teknis maupun ide kreatif dan keterbatasan jumlah kendaraan yang digunakan untuk kunjungan lapangan dan kurangnya fasilitas penelitian serta percobaan menciptakan teknik inovasi meningkatkan produksi tanaman kakao. 
Dari segala permasalahan diatas di temukanlah ide untuk membuat sebuah sistem berbasis desktop yang dimana sistem ini akan mengadopsi sebuah bidang ilmu komputer yaitu sistem pakar dengan menerapkan metode Certainty Factor (CF). Secara umum sistem pakar (expert system) adalah salah satu bidang ilmu komputer yang memanfaatkan komputer sehingga dapat berprilaku cerdas seperti manusia. Sistem ini bertujuan untuk memberikan solusi terkait dari suatu permasalahan yang ada.

Aplikasi berbasis komputer yang banyak dipergunakan dalam penyelesaian permasalahan yang berkaitan dengan pemikiran ataupun keahlian seorang pakar disebut dengan Sistem pakar. Sistem ini mencoba membantu dalam memecahkan masalah yang tidak dapat diselesaikan orang awam dan hanya bisa diselesaikan oleh seorang pakar dibidangnya. Sistem pakar dikatakan berhasil jika sistem ini mampu menghasilkan sebuah keputusan yang sama seperti yang dilakukan oleh pakar aslinya baik pada saat proses pengambilan keputusannya begitu juga dengan hasil keputusannya [4].

Beberapa penelitian yang sudah menerapkan Certainty Factor (CF) diantaranya digunakan untuk mendiagnosa penyakit tanaman buah citrus (lemon) [5]. Mendiagnosa penyakit inflamasi dermatitis imun pada anak [6]. Mendeteksi kerusakan pada mesin laundry electrolux [7]. Mendiagnosa penyakit psoriasis [8]. Mendiagnosa penyakit parasit pada kucing menggunakan [9].

\section{METODE PENELITIAN}

\subsection{Teknik Pengumpulan Data}

Dalam penelitian ini teknik pengumpulan data terdapat beberapa tahapan yang dapat dilakukan, yakni antara lain sebagai berikut.

1. Wawancara

Metode ini dilakukan dengan cara melakukan tanya jawab langsung dengan pakar dalam bidang pertanian Kepala Bidang Perkebunan Kabupaten Aceh Tenggara Riskan, SP.,MM guna mengumpulkan data yang dapat digunakan sebagai acuan dan referensi untuk membuat dan menyusun penelitian ini.

2. Observasi

Metode ini dilakukan dengan pengamatan secara langsung dilapangan tentang dan penyakit tanaman kakao di Desa Pordomuan. Dalam hal observasi, ditemukan masalah terkait kesulitan para petani dalam mendiagnosa penyakit dari tanaman kakao, yang menyebabkan beberapa petani mengalami gagal panen, dan diakhir diisi dengan agenda pengumpulan hasil analisa yang selanjutnya akan diterapkan dalam algoritma sistem.

\subsection{Sistem Pakar}

Sistem pakar juga merupakan sebuah sistem komputer yang berfungsi menyamai atau menyerupai kemampuan dalam mengambil keputusan dari seorang ahli atau pakar. Sistem pakar terdiri dari 2 komponen utama yaitu knowledge base yang berisi pengetahuan dan mesin inferensi yang memproyeksikan kesimpulan. [10]. Sistem kecerdasan buatan dapat melakukan berbagai pekerjaan seperti dan sebaik yang dilakukan oleh manusia bahkan mampu untuk lebih baik dari pada yang dilakukan oleh manusia itu sendiri, sistem kecerdasan buatan dapat memiliki berbagai bentuk, yaitu, sistem robotika, sistem bahasa alami, sistem visual, sistem suara, sistem pakar dan sistem pemahaman [11].

Sistem pakar dibuat dengan tujuan untuk dapat menyelesaikan sebuah masalah yang cukup rumit dan hanya bisa diselesaikan oleh seorang pakar/ahli. Pembuatan sistem pakar bukan untuk menggantikan para pakar/ahli itu sendiri melainkan sistem pakar yang dibuat dapat digunakan sebagai asisten yang berpengalaman [12]. Implementasi sistem pakar ke dalam komputer, dapat menghasilkan beberapa manfaat seperti keakurasian, kecepatan, dan dapat diakses kapan pun sehingga dapat meringankan tugas para pakar dibidangnya. Sistem pakar dipandang sebagai cara penyimpanan pengetahuan pakar dalam bidang tertentu dalam bidang komputer [13].

\subsection{Certainty Factor}

Certainty Factor (CF) dikemukakan oleh Shortliffe dan Buchanan pada 1975 untuk mengakomodasikan ketidakpastian pemikiran (Inexact reasoning) seorang pakar. Seorang pakar, (misalnya dokter sering kali meganalisis informasi yang ada dengan ungkapan seperti "mungkin", "kemungkinan besar", "hampir pasti". Untuk mengakomodasi hal ini menggunakan Certainty Factor (CF) guna menggambarkan tingkat keyakinan

J-SISKO TECH Vol. 5, No. 1, Januari 2022 : 83-94 
pakar terhadap masalah yang dihadapi, metode ini sangat pas untuk sistem pakar yang mendiagnosis sesuatu yang belum pasti [14].

Metode'Net Belief" yang diusulkan oleh E.H Shortliffe dan B.G Buchanan.

$\mathrm{CF}($ rule $)=\mathrm{MB}(\mathrm{H}, \mathrm{E})-\mathrm{MD}(\mathrm{H}, \mathrm{E})$

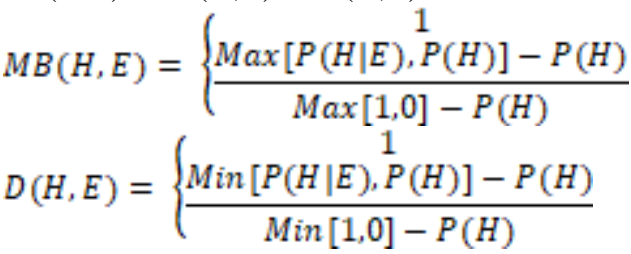

Dimana :

$\mathrm{CF}($ Rule $)=$ faktor kepastian

$\mathrm{MB}(\mathrm{H}, \mathrm{E})=$ measure of belief (ukuran kepercayaan) terhadap

hipotesis $\mathrm{H}$, jika diberikan evidence $\mathrm{E}$ (antara 0 dan 1)

$\mathrm{MD}(\mathrm{H}, \mathrm{E})=$ measure of disbelief, (ukuran ketidakpercayaan) terhadap

evidence $\mathrm{H}$, jika diberikan evidence $\mathrm{E}$ (antara 0 dan 1)

$\mathrm{P}(\mathrm{H}) \quad=$ probabilitas kebenaran hipotesis $\mathrm{H}$

$\mathrm{P}(\mathrm{H} \mid \mathrm{E})$ = probabilitas bahwa $\mathrm{H}$ benar karena fakta $\mathrm{E}$

\section{ANALISA DAN HASIL}

\subsection{Deskripsi Data Obat}

Dari hasil wawancara yang dilakukan adalah berupa data gejala, nama penyakit dan solusi yang dibuat dalam bentuk tabel 1 berikut.

Tabel 1. Data Gejala, Nama Penyakit dan Solusi

\begin{tabular}{|c|c|c|c|}
\hline No & Gejala & Nama Penyakit & Solusi \\
\hline 1 & Buah tampak masak & \multirow{4}{*}{$\begin{array}{l}\text { Penyakit } \\
\text { Penggerek Buah }\end{array}$} & \multirow{4}{*}{$\begin{array}{l}\text { Pemangkasan bentuk pohon kakao } \\
\text { dengan membatasi tinggi tajuk } \\
\text { tanaman maksimum 3-4 meter akan } \\
\text { memudahkan saat pengendalian dan } \\
\text { pemanenan, kemudian pemupukan } \\
\text { dilakukan dengan menggunakan N,P } \\
\text { dan K dengan dosis sesuai anjuran. }\end{array}$} \\
\hline 2 & $\begin{array}{l}\text { sebelum waktunya } \\
\text { Sulit Dipisahkan antara biji } \\
\text { dengan kulit buah }\end{array}$ & & \\
\hline 3 & $\begin{array}{l}\text { Ada tanda-tanda bekas } \\
\text { gesekan dan larva dalam } \\
\text { buah }\end{array}$ & & \\
\hline 4 & $\begin{array}{l}\text { Buah berwarna coklat } \\
\text { kehitaman }\end{array}$ & & \\
\hline 5 & $\begin{array}{l}\text { Penyakit ini menyerang } \\
\text { dengan cara menusuk dan } \\
\text { menghisap cairan sel }\end{array}$ & \multirow{5}{*}{$\begin{array}{l}\text { Penyakit } \\
\text { helopeltis sp }\end{array}$} & \multirow{5}{*}{$\begin{array}{l}\text { Pemangkasan tunas-tunas muda yang } \\
\text { tumbuh di batang, pengelolan } \\
\text { naungan, sanitasi lingkungan, dan } \\
\text { tanaman perangkap }\end{array}$} \\
\hline 6 & $\begin{array}{l}\text { Buah berwarna coklat } \\
\text { kehitaman }\end{array}$ & & \\
\hline 7 & $\begin{array}{l}\text { Buah menjadi kering dan } \\
\text { mati }\end{array}$ & & \\
\hline 8 & $\begin{array}{l}\text { Serangan pada ranting dan } \\
\text { pucuk menyebabkan } \\
\text { kematian }\end{array}$ & & \\
\hline 9 & $\begin{array}{l}\text { Daun-daun mengering dan } \\
\text { gugur }\end{array}$ & & \\
\hline
\end{tabular}


Infeksi pada sisi bagian bawah cabang dan ranting

Ditemukan bintik-bintik

11 yang melekat pada kulit cabang

12

Kulit cabang berkerak dan menjadi busuk

13

Batang dan akar membengkak

14

Ranting rapuh bila dipatahkan

15

Daun-daun mengering dan gugur

16

Buah memburuk, lebih berkilat daripada normal

17

Bercak kecil tidak teratur pada daun

Pada daun tampak bercak coklat kehitaman

19

Garis-garis coklat pada jaringan kayu

20

Lentisel dari ranting yang sakit membesar

Nekrosisi di antara tulang

21 daun seperti gejala

kekurangan $\mathrm{Ca}$

22

Bunga gugur

23

Bercak kecil tidak teratur pada daun
Mengelola kebun agar penyebaran dan infeksi patogen tidak terjadi dengan praktek budidaya yang tepat,Pemotongan cabang/ ranting yang terserang kira-kira $30 \mathrm{~cm}$ di bawah bagian yang terinfeksi, dan dibakar.

bersama dengan lingkaran pohon

Coco swollen kakao yang tampaknya sehat di dekatnya telah menjadi metode utama yang diadopsi untuk mengendalikan penyebaran virus .

Viscular streak dieback

(VSD)

Membersihkan ranting dan buah yang sakit sebelum jamur membentuk badan buah.

Tidak menanam klon-klon yang rentan terhadap penyakit gugur daun di dataran tinggi dan bercurah hujan tinggi. 
Buah berwarna coklat

kehitaman

25

Buah tampak masak

sebelum waktunya

3.2. Penerapan Metode Certainty Factor

Langkah-langkah penyelesaian masalah dengan menggunakan metode Certainty Factor.

1. Menentukan data penyakit dan data Gejala

Berdasarkan hasil penelitian dengan Pakar/Ahli yang didapat sesuai tabel 2 berikut :

Tabel 2. Data penyakit

\begin{tabular}{|c|c|c|c|c|}
\hline No & $\begin{array}{c}\text { Kode } \\
\text { Gejala }\end{array}$ & Nama Gejala & Nama Penyakit & $\begin{array}{c}\text { Kode } \\
\text { Penyakit }\end{array}$ \\
\hline 1 & G01 & Buah tampak masak sebelum waktunya & \multirow{4}{*}{$\begin{array}{c}\text { Penyakit } \\
\text { Penggerek Buah }\end{array}$} & \multirow{4}{*}{ P1 } \\
\hline 2 & G02 & $\begin{array}{l}\text { Sulit Dipisahkan antara biji dengan kulit } \\
\text { buah }\end{array}$ & & \\
\hline 3 & G03 & $\begin{array}{l}\text { Ada tanda-tanda bekas gesekan dan larva } \\
\text { dalam buah }\end{array}$ & & \\
\hline 4 & G04 & Buah berwarna coklat kehitaman & & \\
\hline 5 & G05 & $\begin{array}{l}\text { Penyakit ini menyerang dengan cara } \\
\text { menusuk dan menghisap cairan sel }\end{array}$ & \multirow{4}{*}{$\begin{array}{l}\text { Penyakit } \\
\text { helopeltis } s p\end{array}$} & \multirow{3}{*}{ P2 } \\
\hline 6 & G04 & Buah berwarna coklat kehitaman & & \\
\hline 7 & G06 & Buah menjadi kering dan mati & & \\
\hline 8 & G07 & $\begin{array}{l}\text { Serangan pada ranting dan pucuk } \\
\text { menyebabkan kematian }\end{array}$ & & \multirow{7}{*}{ P3 } \\
\hline 9 & G08 & Daun-daun mengering dan gugur & \multirow{4}{*}{$\begin{array}{l}\text { Penyakit jamur } \\
\text { upas }\end{array}$} & \\
\hline 10 & G09 & $\begin{array}{l}\text { Infeksi pada sisi bagian bawah cabang } \\
\text { dan ranting }\end{array}$ & & \\
\hline 11 & G10 & $\begin{array}{l}\text { Ditemukan bintil-binti yang melekat pada } \\
\text { kulit cabang }\end{array}$ & & \\
\hline 12 & G11 & Kulit cabang berkerak dan menjadi busuk & & \\
\hline 13 & G12 & Batang dan akar membengkak & \multirow{4}{*}{$\begin{array}{l}\text { Coco swollen } \\
\text { shoot virus }\end{array}$} & \\
\hline 14 & G13 & Ranting rapuh bila dipatahkan & & \\
\hline 15 & G08 & Daun-daun mengering dan gugur & & \multirow{2}{*}{ P4 } \\
\hline 16 & G14 & $\begin{array}{l}\text { Buah memburuk, lebh berkilat daripada } \\
\text { normal }\end{array}$ & & \\
\hline 17 & G15 & Bercak kecil tidak teratur pada daun & \multirow{5}{*}{$\begin{array}{l}\text { Viscular streak } \\
\text { dieback(VSD) }\end{array}$} & \multirow{5}{*}{$P 5$} \\
\hline 18 & G16 & $\begin{array}{l}\text { Pada daun tampak bercak coklat } \\
\text { kehitaman }\end{array}$ & & \\
\hline 19 & G17 & Garis-garis coklat pada jaringan kayu & & \\
\hline 20 & G18 & Lentisel dari ranting yang sakit membesar & & \\
\hline 21 & G19 & $\begin{array}{l}\text { Nekrosisi di antara tulang daun seperti } \\
\text { gejala kekurangan } \mathrm{Ca}\end{array}$ & & \\
\hline 22 & G20 & Bunga gugur & \multirow{3}{*}{ Colletotrichium } & \multirow{3}{*}{ P6 } \\
\hline 23 & G15 & Bercak kecil tidak teratur pada daun & & \\
\hline 24 & G04 & Buah berwarna coklat kehitaman & & \\
\hline
\end{tabular}




\begin{tabular}{ccccc}
\hline No & $\begin{array}{c}\text { Kode } \\
\text { Gejala }\end{array}$ & Nama Gejala & Nama Penyakit & $\begin{array}{c}\text { Kode } \\
\text { Penyakit }\end{array}$ \\
\hline 25 & G01 & Buah tampak masak sebelum waktunya & & \\
\hline
\end{tabular}

2. Menentukan Asumsi Data Penyakit

Berdasarkan data-data yang di peroleh maka dapat diasumsikan data penyakit. Example: asumsi Data Penyakit sebanyak 440 pohon dalam 1 Hektar. Data yang penulis teliti terdapat 6 (enam) jenis penyakit, sehingga dapat dideskripsikan seperti dibawah ini:

Dimana :

Dengan rumus $\mathrm{P}(\mathrm{H})=\mathrm{H} / \mathrm{N}$

$\mathrm{P}=$ Probabilitas $\quad \mathrm{H}=$ Hipotesa $\quad \mathrm{N}=$ Jumlah hasil yang mungkin terjadi

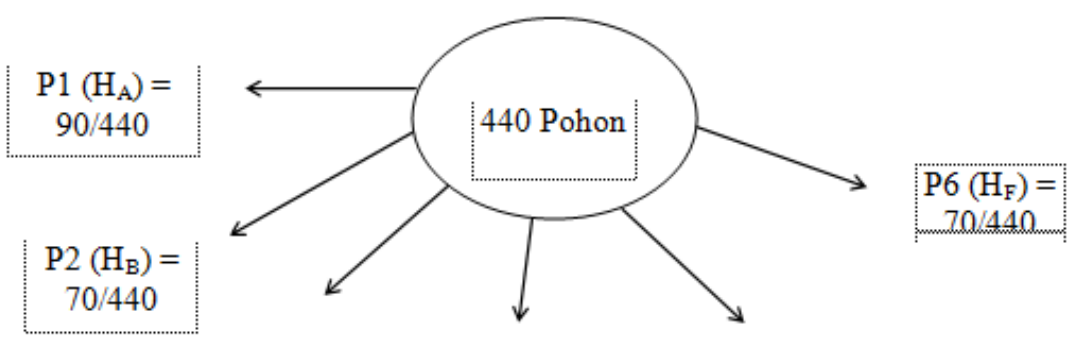

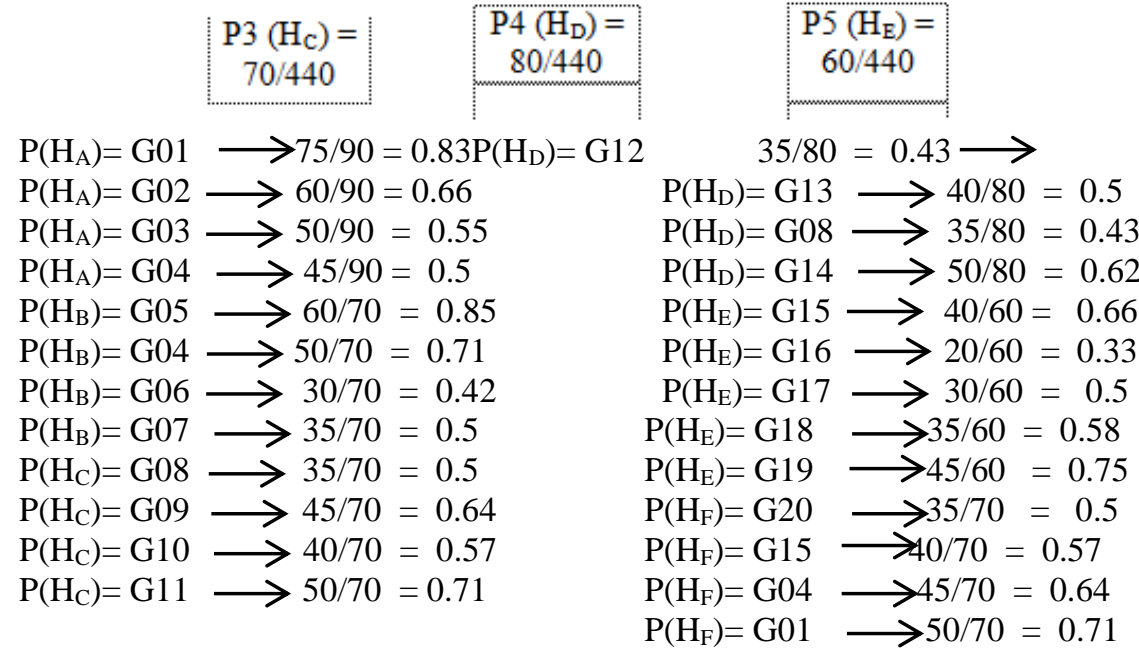

\section{Menentukan MB dan MD}

Setelah mengasumsikan data penyakit selesai, maka akan ditentukan nilai dari MB dan MD dengan rumus di bawah ini :

$$
\begin{array}{r}
\text { Buchanam CF(Rule })=\mathrm{MB}(\mathrm{H}, \mathrm{E})-\mathrm{MD}(\mathrm{H}, \mathrm{E}) . \\
\mathrm{MB}(\mathrm{H}, \mathrm{E})=\left\{\begin{array}{l}
1 \\
\frac{\max [\mathrm{p}(\mathrm{H} \mid \mathrm{E}), \mathrm{p}(\mathrm{H})]-\mathrm{P}(\mathrm{H})}{\max [1,0]-\mathrm{P}(\mathrm{H})}
\end{array}\right. \\
\mathrm{MD}(\mathrm{H}, \mathrm{E})=\left\{\begin{array}{l}
\mathrm{P}(\mathrm{H})=0 \\
\frac{\min [\mathrm{p}(\mathrm{H} \mid \mathrm{E}), \mathrm{P}(\mathrm{H})]-\mathrm{P}(\mathrm{H}) \ldots \ldots \ldots \ldots \ldots}{\min [1.0]-\mathrm{P}(\mathrm{H})}
\end{array}\right.
\end{array}
$$




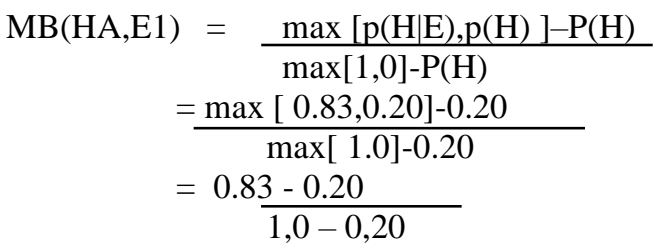

$\mathrm{MB}(\mathrm{HA}, \mathrm{E} 1)=0.78$

Perhitungan nilai MD sebagai berikut:

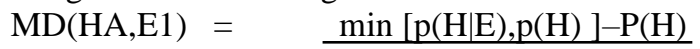

$\min [1,0]-\mathrm{P}(\mathrm{H})$

$=\underline{\min [0.83,0.20]-0.20}$

$$
=\frac{0.20-0.20}{1,0-0.20}
$$

$\mathrm{MD}(\mathrm{HA}, \mathrm{E} 1)=0$

4. Menentukan Nilai CF Dari Setiap Gejala

Berdasarkan nilai $\mathrm{MB}[\mathrm{H}, \mathrm{E}]$ dan nilai $\mathrm{MD}[\mathrm{H}, \mathrm{E}]$ yang diperoleh diatas maka kita dapat menentukan Nilai CF pada setiap gejala penyakit memiliki nilai bobot atau nilai yang tidak mengandung kepastian menggunakan rumus $\mathrm{CF}=\mathrm{MB}[\mathrm{H}, \mathrm{E}]-\mathrm{MD}[\mathrm{H}, \mathrm{E}]$ sesuai tabel 3 berikut :

Tabel 3. Nilai Bobot Pada Tiap Gejala

\begin{tabular}{clc}
\hline Kode Gejala & \multicolumn{1}{c}{ Nama Gejala } & CF \\
\hline G01 & Buah tampak masak sebelum waktunya & 0.78 \\
G02 & Sulit Dipisahkan antara biji dengan kulit buah & 0.57 \\
G03 & Ada tanda-tanda bekas gesekan dan larva dalam buah & 0.43 \\
G04 & Buah berwarna coklat kehitaman & 0.37 \\
G05 & Penyakit ini menyerang dengan cara menusuk dan menghisap & 0.82 \\
G04 & cairan sel & 0.65 \\
G06 & Buah berwarna coklat kehitaman & 0.31 \\
G07 & Serangan pada ranting dan pucuk menyebabkan kematian & 0.41 \\
G08 & Daun-daun mengering dan gugur & 0.41 \\
G09 & Infeksi pada sisi bagian bawah cabang dan ranting & 0.57 \\
G10 & Ditemukan bintil-binti yang melekat pada kulit cabang & 0.49 \\
G11 & Kulit cabang berkerak dan menjadi busuk & 0.65 \\
G12 & Batang dan akar membengkak & 0.3 \\
G13 & Ranting rapuh bila dipatahkan & 0.39 \\
G14 & Buah memburuk, lebih berkilat daripada normal & 0.53 \\
G15 & Bercak kecil tidak teratur pada daun & 0.6 \\
G16 & Pada daun tampak bercak coklat kehitaman & 0.22 \\
G17 & Garis-garis coklat pada jaringan kayu & 0.42 \\
G18 & Lentisel dari ranting yang sakit membesar & 0.51 \\
G19 & Nekrosisi di antara tulang daun seperti gejala kekurangan Ca & 0.71
\end{tabular}




$\begin{array}{lll}\text { G20 } & \text { Bunga gugur } & 0.41 \\ \text { G15 } & \text { Bercak kecil tidak teratur pada daun } & 0.49 \\ \text { G04 } & \text { Buah berwarna coklat kehitaman } & 0.57 \\ \text { G01 } & \text { Buah tampak masak sebelum waktunya } & 0.65\end{array}$

Contoh kasus :

Seorang petani mengeluhkan gejala dibawah ini:

G01 = Buah tampak masak sebelum waktunya

G02 = Sulit Dipisahkan antara biji dengan kulit buah

G06 = Buah menjadi kering dan mati

G07 = Serangan pada ranting dan pucuk menyebabkan kematian

G10 = Ditemukan bintil-binti yang melekat pada kulit cabang

G11 = Kulit cabang berkerak dan menjadi busuk

G13 = ranting rapuh bila dipatahkan

G08 = daun daun mengering dan gugur

$\mathrm{G} 20=$ Bunga gugur

G15 = bercak kecil tidak teratur pada daun

Maka dapat di hitung menggunakan rumus CF COMBINE $(\mathrm{CF} 1, \mathrm{CF} 2)=\mathrm{CF} 1+\mathrm{CF} 2 *(1-\mathrm{CF} 1)$ sebagai berikut:

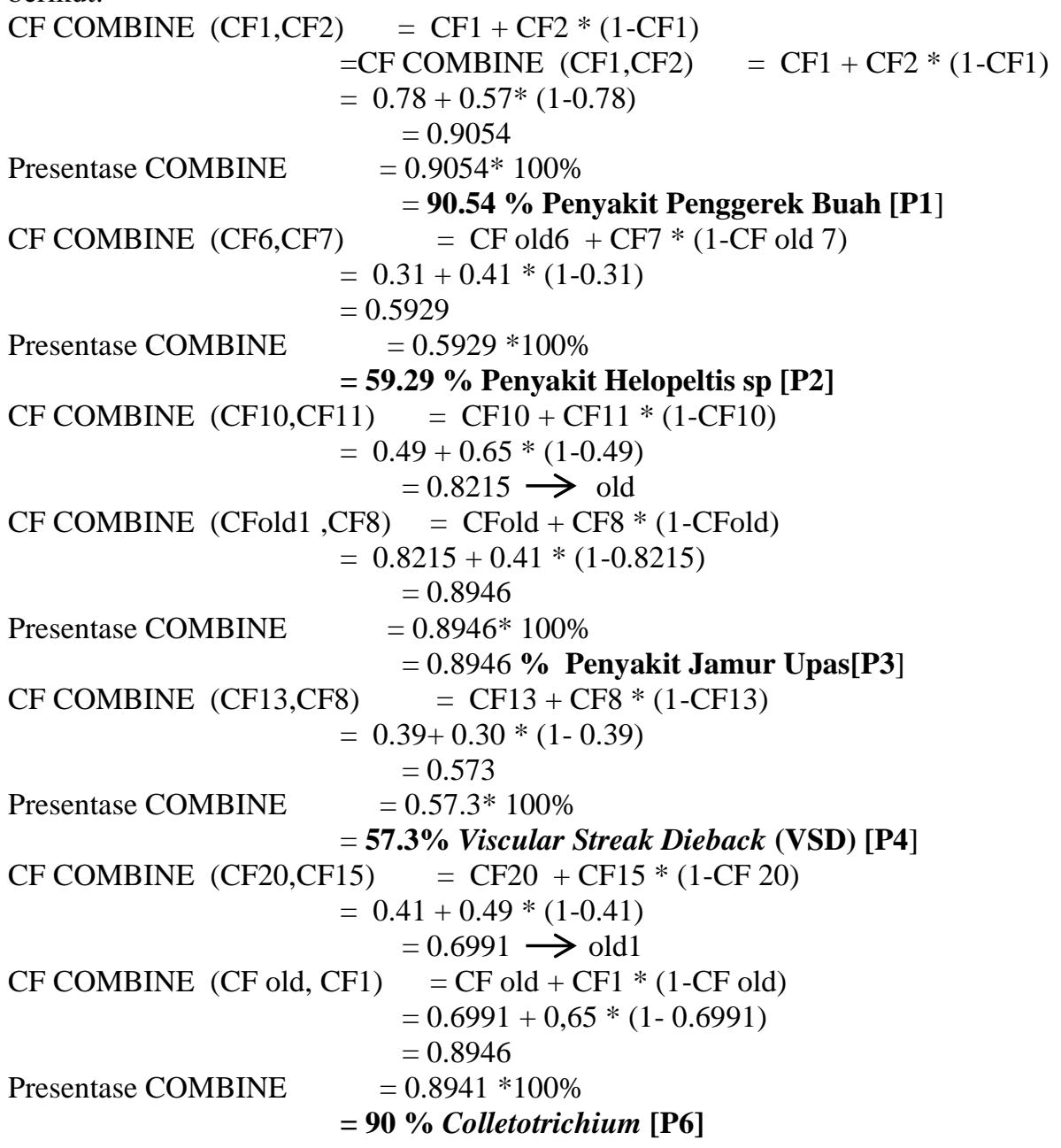

J-SISKO TECH Vol. 5, No. 1, Januari 2022 : 83-94 
Demikian dapat disimpulkan bahwa perhitungan Certainty Factor pada penyakit tanaman kakaoberdasarkan gejala yang dikeluhkan seorang petani memiliki presentase tingkat keyakinan paling tinggi adalah $0,9096 * 100 \%$ dengan presentase $=$ CFCOMBINE $* 100 \%$

$=90.56 \%$ mengarah pada Penyakit Penggerek buah

Sehingga dapat disimpilkan tanaman kakao tersebut di diagnosa terkena Penyakit Penggerek buah.

\subsection{Implementasi Sistem}

1. Form Login

Form Login digunakan untuk mengamankan sistem dari user-user yang tidak bertanggung jawab sebelum masuk ke Menu Utama. Berikut gambar 1 adalah tampilan Form Login :

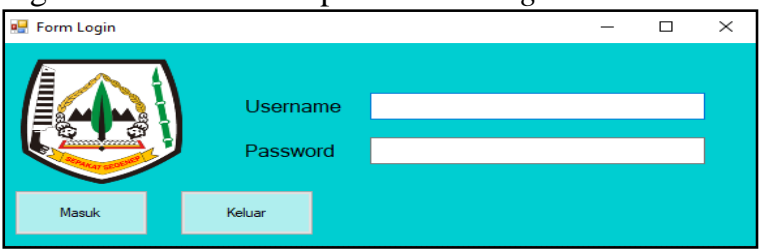

Gambar 1. Form Login

2. FormMenu Utama

FormMenu Utama digunakan sebagai penghubung untuk Form Data Gejala, Form Data Penyakit, Form Diagnosa dan Form Laporan. Berikut gambar 2 adalah tampilan dari form menu utama.

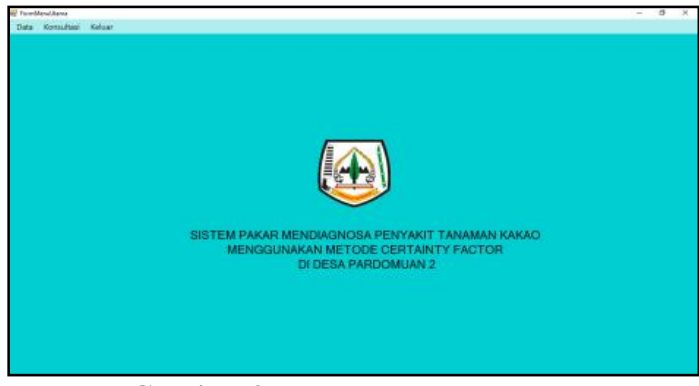

Gambar 2. FormMenu Utama

3. Form Gejala

Form Gejala adalah Form yang digunakan untuk mengelola Data Gejala yang ada pada Sistem. Berikut gambar 3 adalah tampilan form Gejala:

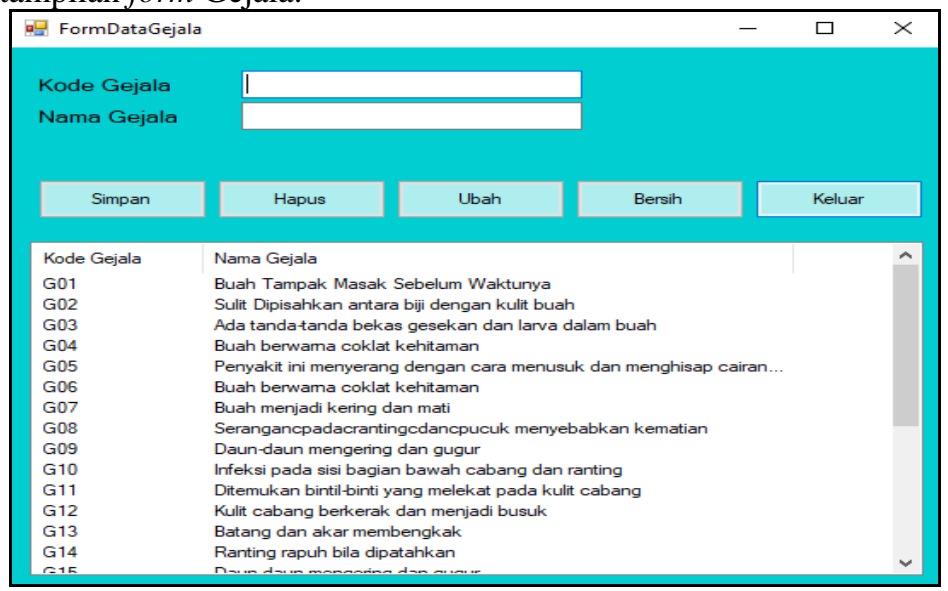

Gambar 3. Form Gejala

4. Form Penyakit

Form Penyakit adalah Form yang digunakan untuk mengelola Data Penyakit yang ada pada Sistem. Berikut gambar 4 adalah tampilan form Data Penyakit: 


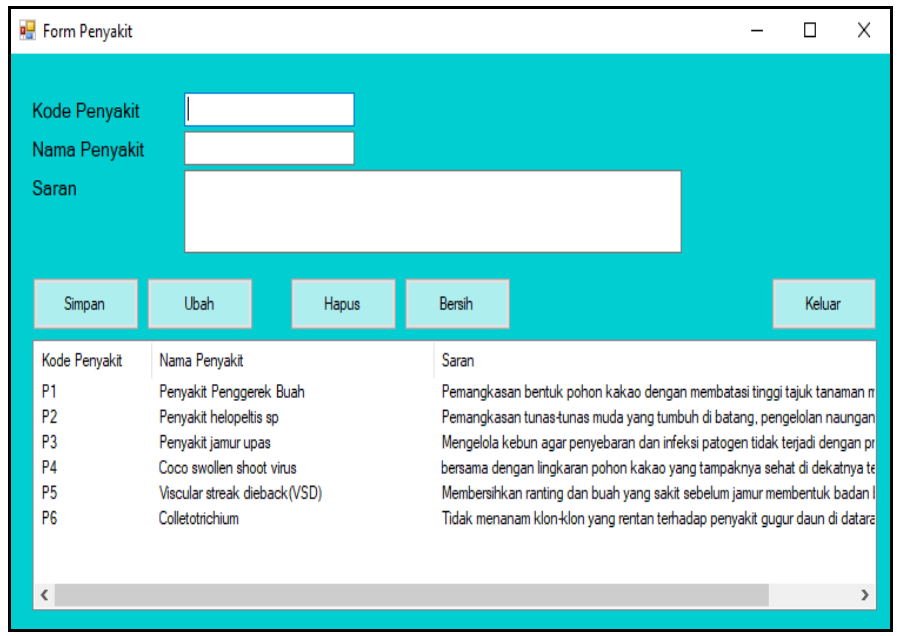

5. Form Diagnosa

Gambar 4. Form Penyakit

Form Diagnosa adalah form yang akan digunakan oleh user untuk menghitung atau mengolah data gejala yang dipilih sesuai dengan yang dialami dengan algoritma Certainty Factor yang nantinya akan menghasilkan diagnosa Penyakit dan user akan memperoleh solusi penanganannya. Berikut gambar 5 adalah tampilan dari form Diagnosa:

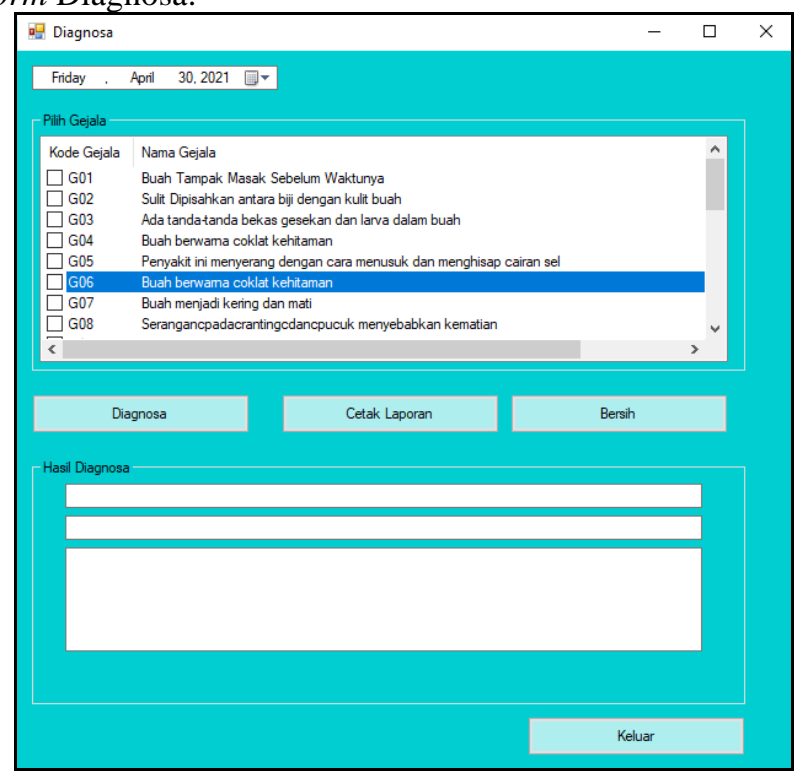

6. Form Laporan

Gambar 5. Form Diagnosa

Form Laporan adalah form yang digunakan untuk menampilkan hasil dari algoritma Certainty Factor tentang mengidentifikasikan bakan anak pada sekolah. Berikut gambar 6 adalah tampilan dari form Laporan: 


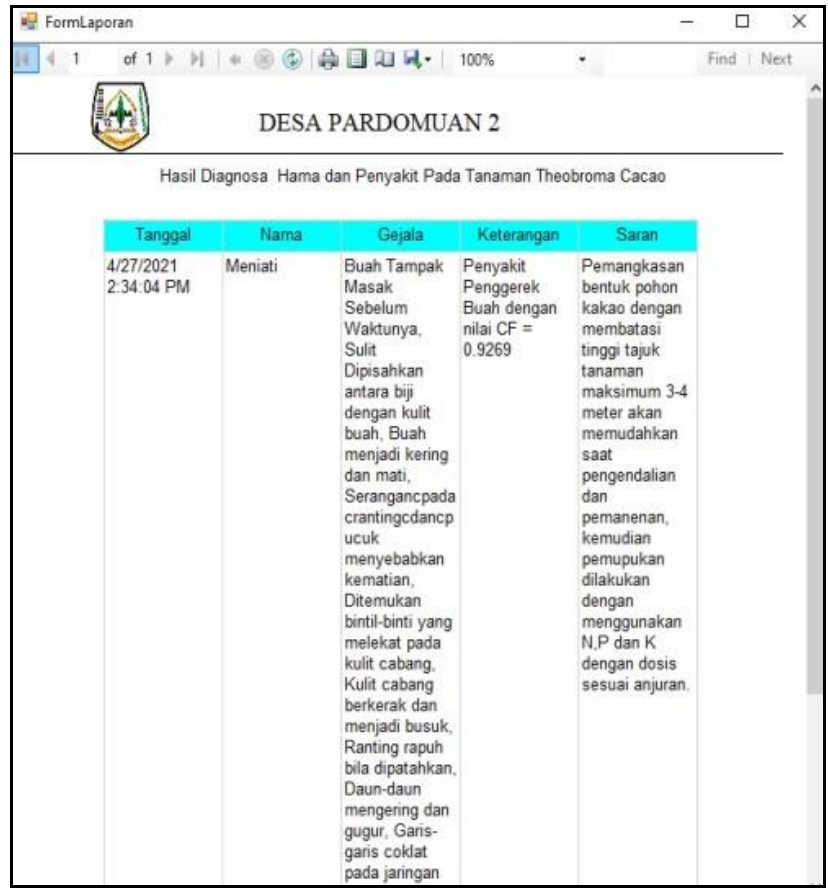

Gambar 6. Form Laporan

\section{KESIMPULAN}

Berdasarkan analisa pada permasalahan yang terjadi dalam kasus yang diangkat tentang penerapan Sistem Pakar Mendiagnosa Penyakit Tanaman Kakao dengan metode Certainty Factor, maka dapat diambil kesimpulan adalah sebagai berikut:

1. Berdasarkan hasil penelitian dan sistem yang dibangun sudah sesuai dengan kebutuhan, yaitu untuk mempermudah para petani dalam mendiagnosa penyakit tanaman kakao dari gejala-gejala yang ada.

2. Berdasarkan hasil analisa, dapat mengadopsi perhitungan metode Certainty Factor dengan keilmuan dari pakarnya langsung yaitu dinas pertanian, yang dapat mempermudah petani dan perangkat desa dalam hal mendiagnosa penyakit tanaman kakao.

3. Berdasarkan pengujian, aplikasi yang dibangun berbasis desktop dengan hasil perarancangan UML dan interface yang sederhana dan mudah digunakan, serta dapat membantu petani kakao dalam mendiagnosa penyakit tanaman kakao dan juga mengefisiensikan waktu tanpa harus menjumpai seorang pakar untuk mengkonsultasikan penyakit yang menyerang tanaman petani, melainkan hanya dengan menginputkan ataupun memilih jenis penyakit yang ada petani sudah dapat mengetahui apa penyakit tanaman kakao tersebut.

\section{UCAPAN TERIMA KASIH}

Terimakasih diucapkan kepada Ibu Nur Yanti Lumban Gaol dan Bapak Ismawardi Santoso yang telah mendukung dalam proses penyelesaian penelitian ini. Kiranya bisa memberi manfaat bagi pembaca dan dapat meningkatkan kualitas penelitian selanjutnya.

\section{REFERENSI}

[1] A. T. Sumpala and M. N. Sutoyo, "Sistem Pakar Untuk Mendiagnosa Hama dan Penyakit Tanaman Kakao Menggunakan Metode Forward Chaining dan Certainty Factor," no. November, pp. 261-267,2018.

[2] Y.Suherlina, B. Yaherwandi, and S. Efendi, "Sebaran dan Tingkat Serangan Hama Penggerek Buah Kakao (Conopomorpha Cramerella Snellen), , J.Agronida, vol. 6, no. 1, pp. 28-33, 2020.

[3] G. A. Rianty, S. T. Informatika, S. Pakar, and B. F. Search, "Penerapan Metode Depth First Search Pada Sistem Pakar Untuk Diagnosa Penyakit,"2010. 
[4] E. Sagala, J. Hutagalung, S. Kusnasari, Z. Lubis, "Penerapan Sistem Pakar Dalam Mendiagnosis penyakit Tanaman Carica Papaya di UPTD . Perlindungan Tanaman Pangan dan H. Menggunakan D. Shafer," vol. 1, no. 1, pp. 95 103, 2021.

[5] N. Yanti, L. Gaol, and A. Info, "Sistem Pakar Mendiagnosa Penyakit Tanaman Buah Citrus (Lemon) Mengggunakan Metode Certainty Factor," vol. 19, no. 1, pp. 1-10, 2020.

[6] P. S. Ramadhan and U. F. S. Sitorus Pane, "Analisis Perbandingan Metode (Certainty Factor, Dempster Shafer dan Teorema Bayes ) untuk Mendiagnosa Penyakit Inflamasi Dermatitis Imun pada Anak," J. SAINTIKOM (Jurnal Sains Manaj. Inform. dan Komputer), vol. 17, no. 2, p. 151, 2018, doi: 10.53513/jis.v17i2.38.

[7] A. T. Novianto and A. Calam, "Sistem Pakar Mendeteksi Kerusakan Pada Mesin Laundry Electrolux Menggunakan Metode Certainty Factor Pada Fast Laundry," vol. 1, no. 2, pp. 1-11, 2021.

[8] P. Andriyani, Z. Azmi, F. Rizky, and A. Calam, "Implementasi Certainty Factor Untuk Diagnosa Penyakit Psoriasis *Sistem Informasi, STMIK Triguna Dharma **Sistem Komputer STMIK Triguna Dharma ***Sistem Informasi, STMIK Triguna Dharma," J. Sains Manaj. Inform. dan Komput., vol. 19, no. 2, pp. 94-99, 2020, [Online]. Available: https://ojs.trigunadharma.ac.id/.

[9] M. Ramadhan, M. Dahria, and H. Jaya, "J-SISKO TECH Jurnal Teknologi Sistem Informasi dan Sistem Komputer TGD Sistem Pakar Untuk Mendiagnosa Penyakit Parasit Pada Kucing Menggunakan Metode Certainty Factor," vol. 4, no. 1, pp. 92-102, 2021.

[10] Zulfian Azmi and Verdi Yasin, S.Kom.,Pengantar Sistem Pakar dan Metode. Mitra Wacana Media, 2017.

[11] W. Y. Yulianti, Liza Trisnawati, and Theresia Manullang, "Sistem Pakar Dengan Metode Certainty Factor Dalam Penentuan Gaya Belajar Anak Usia Remaja," Digit. Zo. J. Teknol. Inf. dan Komun., vol. 10, no. 2, pp. 120-130, 2019, doi:

[12] R. Annisa, "Sistem Pakar Metode Certainty Factor Untuk Mendiagnosa Tipe Skizofrenia," IJCIT (Indonesian J. Comput. Inf. Technol., vol. 3, no. 1, pp. 40-46, 2018.

[13] H. Yusman, R. Efendi, and F. F. Coastera, "Sistem Pakar Deteksi Kerusakan Dini Pada Mesin Mobil Toyota Dengan Metode Certainty Factor (CF)," Rekursif, vol. 5, no. 3, pp. 317-330, 2017, [Online]. Available: http://ejournal.unib.ac.id/index.php/rekursif/\%0A.

[14] R. Rachman and A. Mukminin, "Penerapan Metode Certainty Factor Pada Sistem Pakar Penentuan Minat dan Bakat Siswa SD," Khazanah Inform. J. Ilmu Komput. dan Inform., vol. 4, no. 2, p. 90, 2018, doi: 10.23917/khif.v4i2.6828.

\section{BIOGRAFI PENULIS}

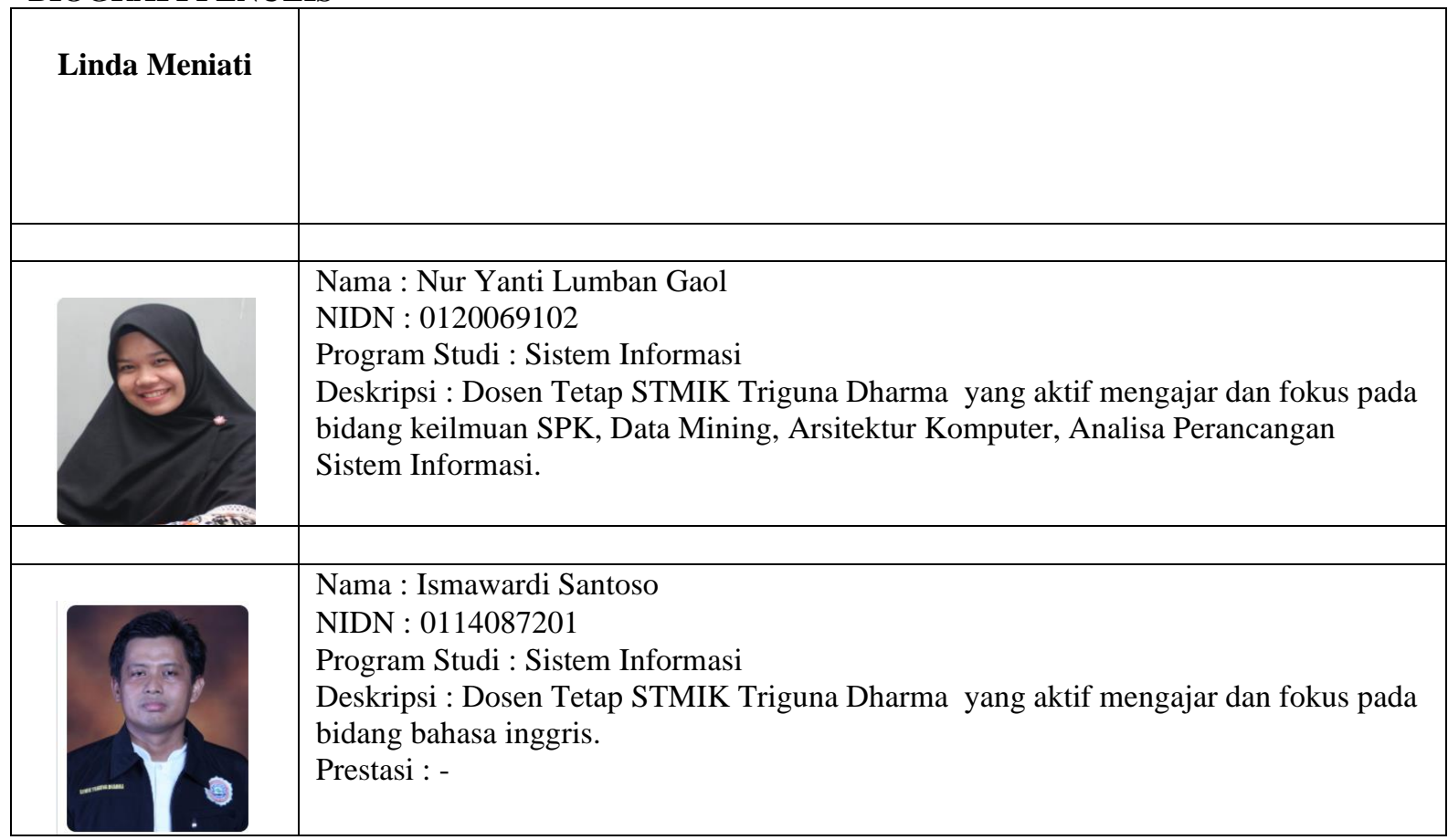

J-SISKO TECH Vol. 5, No. 1, Januari 2022: 83-94 